\title{
Safety and tolerability of tafluprost in treatment of elevated intraocular pressure in open-angle glaucoma and ocular hypertension
}

This article was published in the following Dove Press journal:

Clinical Ophthalmology

15 October 2010

Number of times this article has been viewed

\section{Dorota Pozarowska}

Department of Ophthalmology,

Medical University, Lublin, Poland
Correspondence: Dorota Pozarowska

Department of Ophthalmology,

Medical University of Lublin, I

Chmielna Str, 20-079, Lublin, Poland

Tel +48 8I5 $326 \quad 149$

Fax +48815326149

Email dpozarowska@wp.pl
Abstract: Glaucoma is one of the most common neuropathies of the optic nerve. An elevated intraocular pressure (IOP) is a well documented risk factor for the development and progression of this disease. Until now, IOP reduction is the only well documented successful method of glaucoma treatment. Among the many hypotensive drugs, prostaglandin analogs are proved to be the most potent antiglaucoma agents, with very few systemic side effects. A new prostanoid FP receptor analog, tafluprost, has been introduced into the medical treatment of glaucoma and ocular hypertension. Many studies have shown that it is an efficient IOP-lowering drug, and that it is safe and well tolerated. A preservative-free tafluprost formulation is as potent as a preserved one, but it has fewer and milder toxic effects on the eye.

Keywords: tafluprost, prostaglandins, pharmacokinetics, safety, toxic effects, preservatives

\section{Introduction}

Glaucoma is one of the most common neuropathies of the optic nerve. It causes progressive atrophy of the optic disc resulting in typical defects in the visual field. ${ }^{1}$ It can lead to total loss of vision if left untreated. ${ }^{2,3}$ Indeed glaucoma is the second most common cause of blindness worldwide. ${ }^{3,4}$ Unfortunately, the pathogenesis of this disorder is not fully explained. Because elevated intraocular pressure (IOP) is known to be the main risk factor for development and progression of glaucoma, its therapy relies nowadays on IOP reduction. ${ }^{5-10}$ Topical use of antiglaucoma drugs is probably the most commonly used tool for this. Among the many topical hypotensive medications, prostaglandin analogs are proved to be the most potent in lowering IOP and with very few systemic side effects. ${ }^{11,12}$ For these reasons, they are recommended as first-line therapy for this disease. ${ }^{3,11,13,14}$

Prostaglandin analogs were first proposed for glaucoma treatment by Camras and Brito. ${ }^{14-16}$ Nowadays, derivatives of prostaglandin $F_{2 \alpha}$, ie, latanoprost, travoprost, unoprostone, and a prostamide, bimatoprost, are commercially available. In van der Valk's meta-analysis, latanoprost reduced IOP by $28 \%-31 \%$ from baseline, travoprost by $29 \%-31 \%$, and bimatoprost by $28 \%-33 \% .{ }^{12}$ Latanoprost and travoprost are selective prostanoid FP receptor agonists, and by binding to these receptors they exert their IOPlowering effect. ${ }^{17-21}$ Bimatoprost is a prostamide, the exact molecular mode of action of which is not clearly understood..$^{14,18,21}$ All these compounds decrease IOP by increasing aqueous outflow, mainly through the uveoscleral (unconventional) route. ${ }^{14,22}$ In young individuals, up to $30 \%$ of aqueous fluid flows out through the unconventional route, but this drops during aging. ${ }^{22}$ Hypotensive lipids can increase aqueous fluid outflow by up 
to $50 \% .^{22}$ Moreover, they do not have an effect on aqueous production. ${ }^{14}$ They probably act by increasing the activity of matrix metalloproteinases and widening the spaces between ciliary muscle bundles. ${ }^{14}$ It has been found that the increase in uveoscleral outflow may also be due to relaxation of the ciliary muscle, leading to widening spaces between muscle bundles. ${ }^{14}$ Ester forms of $\mathrm{PGF}_{2 \alpha}$ derivatives penetrate the cornea much better. This is why all prostanoids except for bimatoprost are administered topically as prodrugs. After entering the cornea, they are hydrolyzed by corneal esterases to their active carboxylic acid forms. ${ }^{17}$

\section{Preclinical and animal studies}

Prostaglandin derivatives have a strong, long-lasting, stable IOP-lowering effect with few systemic side effects. ${ }^{4,14,17}$ Unfortunately, they may induce local adverse side effects, including conjunctival and ocular hyperemia, iris and periocular skin pigmentation, and eyelash growth. ${ }^{4,17,23}$ There have been efforts to find other prostanoid FD receptor agonists which are more potent in reducing IOP but with fewer and milder side effects. ${ }^{17,21,24}$ In preclinical in vitro and in vivo studies, Nakajama et al tested different PGF $_{2 \alpha}$ derivatives and found that 15,15 difluoro $\mathrm{PGF}_{2 \alpha}$ derivatives retained iris constrictor activity, decreased IOP in conscious monkeys, but did not increase the melanin content of cultured B16-F10 melanoma cells. ${ }^{17}$ This last observation was confirmed by Tagaki et al, who also demonstrated an ocular hypotensive effect for this compound. This effect was present in normotensive monkeys and in laser-induced ocular hypertension. The effect was dose-dependent, with a peak at eight hours after administration. ${ }^{24}$ Moreover, the effect was stronger and more continuous than that induced by latanoprost. ${ }^{24}$ Reduction of IOP was dose-dependent in the eyes of ddY mice. ${ }^{19}$ This effect was similar to the effect of travoprost, but stronger and more longer-lasting than after administration of latanoprost. ${ }^{19}$ In this animal model, Ota et al also found that tafluprost lowered IOP via prostanoid FP receptors, and that part of the hypotensive effect may be related to FP receptor-mediated prostaglandin production and stimulation of EP3 receptors. ${ }^{20}$ This IOP-lowering effect in mice was confirmed by Akaishi et al. ${ }^{25}$

It has been postulated that alterations in optic nerve head blood flow may be involved in the pathogenesis of glaucoma. ${ }^{1,26}$ For this reason, improvement in ocular blood flow by glaucoma therapy may be helpful. Studies assessing the influence of the available prostaglandin analogs on ocular blood flow have yielded both positive and negative results. ${ }^{14}$ In a study by Izumi et al tafluprost $0.0015 \%$ significantly increased retinal blood flow and blood velocity as measured by laser Doppler velocimetry in cats. ${ }^{29}$ This observation was then confirmed by Akaishi et $\mathrm{al}^{27}$ who found that optic nerve head blood flow increased in rabbit eyes after 28 days' administration of any of the three $F_{2 \alpha}$ prostaglandin analogs, ie, tafluprost, latanoprost, or travoprost. Moreover, the increase induced by tafluprost was greater than that induced by latanoprost or travoprost. ${ }^{27}$ Tafluprost also increased optic nerve head blood flow in both normal and experimental glaucomatous eyes in monkeys. ${ }^{28}$ Dong et al wanted to determine if tafluprost could relax precontracted rabbit ciliary arteries, and found that it induced concentration-dependent relaxation but by a mechanism that was independent of endothelial-derived factor. ${ }^{26}$ In the future, these findings are likely to be shown to be real additional effects of antiglaucoma drugs. At this time we do not possess reliable tools for blood flow measurement, and thus the beneficial role of improvement in ocular blood flow cannot as yet be ascertained. ${ }^{29,30}$

Another interesting question concerning antiglaucoma agents concerns their neuroprotective properties. A direct antiapoptotic effect in cultured retinal ganglion cells (RGC5 s) and rat retinal ganglion cells with optic nerve crush was identified by Kanamori et al. In an in vitro model, tafluprost promoted cell viability in a dose-dependent manner, significantly reducing the number of caspase 3-positive cells and suppressing $\left[\mathrm{Ca}^{2+}\right]$ evoked by exogenous glutamate. In an in vivo rat model, tafluprost increased the survival rate of ganglion cells in eyes treated with this drug for 14 days after optic nerve crush. ${ }^{31}$ These observations suggest that tafluprost possesses an antiapoptotic effect in retinal ganglion cells in rats.

\section{Pharmacology, pharmacokinetics, and clinical efficacy}

Tafluprost (1-methylethyl (5Z)-7-[(1R,2R,3R,5S)-2-[(1E)3,3-difluoro-4-phenoxy-1-butenyl]-3,5-dihydroxycyclopentyl]-5- heptenoate) ${ }^{24,31}$ is a 16-phenoxy analog of $\mathrm{PGF}_{2 \alpha}$, with a 15,15 -difluoro substitution. ${ }^{21}$ It is presently available in two formulations, ie, with benzalkonium chloride (BAK)Tapros $^{\circledR}$ in Japan (Santen Pharmaceutical Co. Ltd., Osaka, Japan) and preservative-free in Europe, ie, Taflotan ${ }^{\circledR}$ (Santen Oy, Finland), both in $0.0015 \%(15 \mu \mathrm{g} / \mathrm{mL})$ concentrations. ${ }^{21}$ Tafluprost differs from the other prostanoids available on the market because it possesses two fluorine atoms at the carbon 15 position, instead of the hydroxyl group present in latanoprost, travoprost, and bimatiprost. ${ }^{14,22}$ It is an isopropyl ester (AFP-168) and, like other prostaglandin analogs, is 
rapidly hydrolyzed by corneal esterases to the free acid of tafluprost (AFP-172), which is its active form. ${ }^{14,21,24}$ AFP172 is a very potent FP receptor agonist, with a $\mathrm{K}_{\mathrm{i}}$ of $0.4 \mathrm{~b}$ $\mathrm{nM} \cdot{ }^{17,24}$ Its affinity for the human prostanoid FP receptor is 12 times that of the carboxylic acid in latanoprost and 1700 times that in unoprostone. It also has a 126-fold higher affinity for FP receptors than for EP3 receptors, and negligible affinity to other prostanoid receptors (DP, EP2, IP, TP). ${ }^{24}$ Tafluprost increases in vivo uveoscleral outflow as measured by fluorophotometry. ${ }^{24}$ After either single or repeated topical dosing, the plasma concentration of tafluprost is low. Moreover, it is cleared rapidly from the circulatory system. Its active form, ie, tafluprost acid, can be detected in plasma for up to one hour after topical administration, with a peak at 10 minutes. $^{3}$ It is thought that the pharmacologic profile of this compound is similar to that of other prostaglandins available on the market. ${ }^{32}$

The pharmacodynamics, safety, and tolerability of tafluprost in healthy volunteers were assessed in a clinical, masked, placebo-controlled Phase I study. ${ }^{23}$ Tafluprost $0.0025 \%$ and $0.005 \%$, latanoprost $0.005 \%$, and placebo were given for seven days. The decline in IOP from baseline was $4.3 \mathrm{mmHg}$ for tafluprost $0.0025 \%, 6.8 \mathrm{mmHg}$ for tafluprost $0.005 \%, 5.3 \mathrm{mmHg}$ for latanoprost, and $3.1 \mathrm{mmHg}$ for placebo. The decrease in IOP values versus baseline was significant for all treatment groups, and superior with tafluprost $0.005 \%$ to values with placebo and latanoprost $0.005 \%$. In another placebo-controlled Phase I study, healthy volunteers were given sequential ascending doses of tafluprost, ie, $0.0001 \%, 0.0005 \%, 0.0025 \%$, and $0.005 \% .{ }^{4}$ For all these doses, a decreasing IOP effect was present as compared with placebo. The effect was dosedependent and significant for concentrations of $0.0005 \%$, $0.0025 \%$, and $0.005 \%$. The effect was maximal at 12 hours after administration and lasted throughout the duration of treatment. ${ }^{4}$ The therapeutic concentration of tafluprost was set at $0.0015 \%$ as a result of a Phase II dose-response study performed in Japan. ${ }^{21}$ In a randomized, double-masked, controlled, multicenter, multinational Phase II study, Traverso et al assessed the duration and stability of the IOP-lowering effect and tolerability of tafluprost $0.0015 \%$ compared with latanoprost $0.005 \%$ in patients with primary open-angle glaucoma, exfoliation glaucoma, or ocular hypertension. ${ }^{33}$ They observed that maximum reduction of IOP was reached by day 7 of treatment and sustained until day 42 . They showed that tafluprost $0.0015 \%$ decreased IOP from baseline by $9.7 \pm 3.3 \mathrm{mmHg}$ and latanoprost $0.005 \%$ by $8.8 \pm 4.3 \mathrm{mmHg} .{ }^{33}$
Phase III clinical studies were conducted in Japan and in Europe. In the first one, the efficacy of tafluprost with that of latanoprost in 109 patients with open-angle glaucoma and ocular hypertension were compared. ${ }^{21}$ After four weeks of administration, they observed reduction in IOP by $6.6 \pm 2.5 \mathrm{mmHg}(27.6 \pm 9.6 \%)$ in the tafluprost group and by $6.2 \pm 2.5 \mathrm{mmHg}(25.9 \pm 9.7 \%)$ in the latanoprost group. ${ }^{21}$ A second Phase III study involving 351 Japanese patients with open-angle glaucoma or ocular hypertension showed that the reduction in IOP from baseline was stable throughout 52 weeks and varied from 4.9 to $5.7 \mathrm{mmHg} .{ }^{21}$ A potent effect of tafluprost $0.0015 \%$ on IOP and the safety of this medication were also demonstrated in a randomized, parallel-group, doublemasked European Phase III study conducted in 49 centers in eight countries for up to 24 months. ${ }^{34}$ The objective of this study was to compare the efficacy and safety profiles of tafluprost $0.0015 \%$ and latanoprost $0.005 \%$ in 533 patients with open-angle glaucoma and ocular hypertension. Patients had not only primary open-angle glaucoma but also pigmentary and exfoliative disease. Both drugs exerted a potent and significant IOP-lowering effect throughout the study, with average decreases of $6-8 \mathrm{mmHg}(27 \%-31 \%)$ for tafluprost and $7-9 \mathrm{mmHg}(29 \%-35 \%)$ for latanoprost. These results are in line with those of other prostaglandins, as shown in the van der Valk meta-analysis. ${ }^{12}$ After 24 months, the mean decrease in IOP from baseline was $7.1 \mathrm{mmHg}(29.1 \%)$ in the group treated with tafluprost and $7.7 \mathrm{mmHg}(32.2 \%)$ in the group treated with latanoprost. ${ }^{34}$

The primary aim of the randomized, investigator-masked, multicenter, crossover Phase III study described by Hamacher et al was to evaluate the pharmacodynamics and safety of preserved and preservative-free tafluprost $0.0015 \%$ in patients with open-angle glaucoma or ocular hypertension. These investigators observed similar reductions in IOP of $>5 \mathrm{mmHg}$ with preservative-free and preserved formulations. ${ }^{11}$ A preservative-free tafluprost $0.0015 \%$ formulation also lowered IOP effectively in a population with poor IOP control with prior medications. Mean IOP reduction in 544 screened patients was from $19.4 \pm 5.0 \mathrm{mmHg}$ at baseline to $15.3 \pm 3.5 \mathrm{mmHg}$ after 12 weeks of tafluprost treatment. In total, $79.5 \%$ of eyes treated with the preservative-free formulation of tafluprost achieved IOP $\leq 18 \mathrm{mmHg} 12$ weeks after switching medication. ${ }^{35}$ Other Phase III studies indicated that tafluprost, like other prostaglandin analogs, may also exert an additional IOP-lowering effect when administered together with the $\beta$-blocker, timolol, in cases when monotherapy is not adequate. ${ }^{36}$ 


\section{Safety and tolerability}

In 2007, Sutton et al observed in a Phase I clinical study that systemic safety was similar for tafluprost, latanoprost, and placebo when administered to eyes. Investigators did not observe clinically significant changes in laboratory parameters, vital signs, or electrocardiographic parameters in any of 49 participants throughout the course of the study. Visual acuity and funduscopic pictures of tested eyes were also stable. Aqueous flare, measured by a laser flare cell meter, decreased over time. Ocular adverse effects were only mild to moderate in severity. The most common side effect was ocular hyperemia. This was more frequent after administration of tafluprost in concentrations of $0.0025 \%$ or $0.005 \%$ than after administration of latanoprost $0.005 \%{ }^{23}$ The incidence of photophobia was greater in the tafluprost group than in the latanoprost group. It is noteworthy that the doses used in this study exceeded the dose in the currently available preparations, ie, $0.0015 \%$. Similar observations were made in another Phase I study. ${ }^{4}$ Tafluprost was well tolerated. The most frequently observed adverse effect was mild, concentration-dependent hyperemia. ${ }^{4}$ Mild chemosis was also observed in two of 16 patients receiving tafluprost $0.0001 \%$. Interestingly, the authors stated that rates of adverse effects were similar for the tafluprost $0.0001 \%$ and $0.0025 \%$ and latanoprost $0.005 \%$ groups, but rates of ocular hyperemia was significantly lower in eyes receiving latanoprost. ${ }^{4}$ These authors did not find either cells or flare in the anterior chamber or abnormalities of the iris, lens, or vitreous humor in any eyes during the study. ${ }^{4}$ All adverse events described in the two aforementioned studies were mild to moderate and did not result in treatment discontinuation. ${ }^{4,23}$ Similar observations were made by Uusitalo et al who administered preserved and preservative-free formulations of tafluprost. No serious side effects or withdrawals occurred during their study. Ocular adverse events were of mild or moderate severity, with the most prevalent being ocular hyperemia. ${ }^{3}$

A Phase III study described by Uusitalo analyzed the safety of tafluprost $0.0015 \%$ versus latanoprost $0.005 \%$ over 24 months in a representative group of 533 patients. ${ }^{34}$ Both drugs were well tolerated. Reported adverse events were only mild to moderate. The authors found that during the 24 month study period, at least one adverse event was reported by 176 of $264(66.7 \%)$ of patients receiving tafluprost, and by 162 of 264 (61.4\%) of patients receiving latanoprost. Nonocular adverse events were reported by 133 (50.4\%) patients treated with tafluprost, and by $114(43.2 \%)$ with latanoprost, but only 11 in the tafluprost group and nine in the latanoprost group, respectively, were considered to be related to treatment. ${ }^{34}$ The authors did not find any clinically significant changes in blood pressure or heart rate during the 24 month study period, or in laboratory parameters up to 12 months. LogMAR scale scores for best corrected visual acuity remained stable throughout the study. Ocular adverse effects were reported by $48.1 \%$ of patients in the tafluprost group and by $44.3 \%$ patients in the latanoprost group. Most frequently reported were conjunctival hyperemia and ocular redness. The stimulating effect on eyelash growth was absent or mild in $>90 \%$ of patients after month 24 in both the tafluprost and latanoprost groups. A slight overall tendency towards corneal thinning was observed in both groups of patients during the study, but the changes were comparable between the groups. ${ }^{34}$

It is known that $\mathrm{PGF}_{2 \alpha}$ derivatives cause an increase in iris and periocular skin pigmentation. ${ }^{17,21}$ This was observed in $43 \%-56 \%$ of patients receiving latanoprost for longer than one year. ${ }^{37}$ Moreover, the pigmentation increases with prolonged therapy. ${ }^{23,37}$ Latanoprost was reported to increase melanogenesis in cultured melanoma cells. The carboxylic acid in latanoprost increased the melanin content of cultured B16-B10 melanoma cells in a dose-dependent manner, but derivatives possessing two fluorine atoms at the 15-position as AFP-172 (carboxylic acid of tafluprost) did not, even at the maximal dose. ${ }^{17}$ The same results were obtained in 2004 by Tagaki et al. ${ }^{24}$ Such observations led to the suggestion that tafluprost may induce a lower incidence of iris and periocular skin pigmentation than latanoprost. ${ }^{24}$ In a long-term Phase III study, Uusitalo et al reported slightly more cases of iris pigmentation in the group treated with latanoprost (28\%) than in those treated with tafluprost (26.1\%), but these differences were not significant. ${ }^{34}$

\section{Toxic adverse effects}

Toxic adverse reactions to antiglaucoma topical medication may be only minimal or be very severe. The cytotoxic effects of these drugs cause damage and death of conjunctival and corneal epithelial cells. This can lead to epitheliopathy of the cornea and conjunctiva. Inflammation may be the first sign of a toxic drug effect on superficial tissues of the eye. This is caused by activation of the inflammatory response in the conjunctiva, either acute or chronic. This could be papillary, with generalized injection, or follicular, caused by proliferation of lymphocytes and plasma cells. ${ }^{38}$ Unfortunately, such inflammatory changes create a potential risk for failure of further glaucoma filtration surgery. ${ }^{39,40}$ These changes may also lead to keratinization and conjunctival scarring, with symblepharon formation, known as drug-induced pseudopemphigoid. ${ }^{3,11,38}$ Many of 
these undesirable effects are connected with the preservatives present in eye drop formulations. ${ }^{2}$ The adverse influence of preservative-containing topical antiglaucoma medications on cells and tissues on the eye surface is well documented in in vitro and in vivo studies. ${ }^{2,32,38,41}$ BAK is the most commonly used preservative in eye drops. ${ }^{42}$ It has already been found that this compound exerts cytotoxic (proapoptotic and pronecrotic) effects on the ocular surface and trabecular meshwork cells. ${ }^{43-45}$ It also causes reduction of cellular viability, infiltration of conjunctival stroma, and overexpression of inflammation- or apoptosis-related molecules, such as Apo-2,7, Fas (CD45), HLA-DR, ICAM-1..$^{32,38,46-52}$ Moreover, decreased expression of MUC5AC on the conjunctival cells were found in impression cytology specimens taken from patients treated locally with antiglaucoma drugs containing BAK. This phenomenon may explain the high prevalence of dry eye syndrome in patients after prolonged antiglaucoma therapy. $34,50,53$

Solutions which are preservative-free, have lower BAK concentrations, or contain alternative preservatives were introduced into topical glaucoma therapy to minimize side effects. ${ }^{2}$ Among the widely used prostaglandin analogs, only tafluprost is available in a BAK-free formulation., ${ }^{3,42}$ A preservative-free solution of tafluprost showed reduced toxicity in human conjunctival epithelial cell lines when compared with preserved latanoprost, travoprost, and bimatoprost. ${ }^{54}$ Tafluprost had low proapoptotic/pro-oxidative effects in vitro when compared with preservative-containing formulations..$^{54}$ Liang et al assessed conjunctival and corneal reactions to preservative-free tafluprost, commercially available latanoprost, and benzalkonium chloride $0.02 \%$ in in vivo studies. ${ }^{45}$ Corneal epithelium confocal microscopy in vivo revealed partial desquamation of epithelial cells, irregular cell shapes, anisocytosis and loss of cell borders, abnormal reflectivity patterns, swollen cells, and inflammatory infiltrations in rabbit eyes treated with latanoprost and BAK solution. Rabbit corneas treated with preservative-free tafluprost were almost normal, with the epithelium having a regular polygonal mosaic appearance, brightly reflective nuclei, and no obvious desquamation or swelling. A slight inflammatory infiltrate in the anterior corneal stroma was observed only after administration of BAK. Inflammatory infiltrations in the peripheral cornea and the limbus area were noted after exposure to latanoprost or BAK, but not after exposure to preservative-free tafluprost. ${ }^{45}$ Similarly, conjunctival stroma vessels showed rolling of inflammatory cells after installation of BAK or latanoprost. After installation of preservative-free tafluprost, normal blood vessels were observed, without any rolling of inflammatory cells. Moreover, significant inflammatory infiltration in specimens taken from eyes exposed to latanoprost and abundant inflammatory cell patches in those exposed to BAK were observed in conjunctival impression cytology specimens. ${ }^{45}$ Specimens taken from eyes exposed to latanoprost and BAK showed a higher expression of CD45+ cells than those exposed to tafluprost without preservative. Similarly, expression of tumor necrosis factor receptor 1 in conjunctival impression cytology samples was highest in patients treated with BAK or latanoprost. Only a few TUNEL+ cells were observed after installation of preservative-free tafluprost but more of these cells were present after installation of latanoprost or BAK.$^{45}$ These observations established the lower toxicity of the preservative-free formulation to the anterior segment of the eye. ${ }^{45}$

BAK is thought to be an ocular penetration enhancer for topically administered drugs, because it increases the corneal permeability of pharmacologic agents. ${ }^{42,55}$ Pellinen and Lokkila evaluated corneal penetration of preserved and preservative-free tafluprost $0.0015 \%$ into rabbit aqueous humor after topical application. They noticed that there were no significant between-group differences in mean concentrations of tafluprost acid in the aqueous humor. They concluded that BAK at the concentration used in the tafluprost formulations did not affect corneal penetration of this drug into rabbit aqueous humor. ${ }^{55}$ It is possible that tafluprost has its own high corneal penetrating ability and BAK would not enhance it. ${ }^{55}$ In a Phase I study evaluating the pharmacokinetics and efficacy of preserved and preservative-free tafluprost, Uusitalo et al did not observe any significant differences in pharmacokinetic parameters between the formulations, after either single or repeated dosing. ${ }^{3}$ Ocular hyperemia occurred with the same frequency in both groups, but was predominantly of moderate severity in eyes treated with preserved tafluprost, and of mild severity in those treated with the preservative-free formulation. ${ }^{3}$ The safety of preserved and preservative-free tafluprost was also assessed in a Phase III study. ${ }^{11}$ In contrast with the findings of Uusitalo et al it was shown that conjunctival hyperemia was reported more often by people using preservativefree tafluprost. ${ }^{11}$ The aforementioned studies showed that IOP reduction obtained by preservative-free tafluprost is equivalent to that achieved by the preserved formulation. It seems that removing the preservative BAK from the tafluprost formulation does not change the IOP-lowering properties of preparation. ${ }^{11,42}$ Because the aim of designing a preservative-free prostaglandin formulation was to reduce 
toxic effects and clinical complications in patients treated for glaucoma and ocular hypertension, it was reasonable to check if preservative-free tafluprost was a genuine alternative for patients receiving prostaglandins other than tafluprost. Uusitalo et al investigated the hypotensive effect and tolerability of preservative-free tafluprost in patients with open-angle glaucoma and ocular hypertension exhibiting ocular surface side effects during latanoprost treatment. ${ }^{32}$ Twelve weeks after switching from preserved latanoprost to preservative-free tafluprost, IOP was maintained at the same level. IOP values were $16.8 \pm 2.5 \mathrm{mmHg}$ at baseline and $16.4 \pm 2.7 \mathrm{mmHg}$ at weeks 2,6 , and 12 of tafluprost treatment. ${ }^{32}$ The number of patients with ocular side effects, ie, conjunctival hyperemia, and corneal and conjunctival fluorescein staining, was reduced by $50 \%$ after switching the drugs. The same was reported for other ocular symptoms, including itching, tearing, irritation, burning, stinging and foreign body sensation. After 12 weeks of tafluprost preservative-free treatment, fluorescein break-up time increased from $4.5 \pm 2.5$ seconds at baseline to $7.8 \pm 4.9$ seconds $(P<0.001) .{ }^{32}$ Results of immunocytologic testing of impression cytology samples revealed that, after 12 weeks of treatment with preservative-free tafluprost in patients previously using latanoprost, there was a significant reduction in those expressing abnormal levels $(<7 \%)$ of MUC5AC-positive goblet cells and abnormal levels $(>40 \%)$ of HLA-DRpositive epithelial cells. ${ }^{32}$ This observations may indicate a less harmful influence of preservative-free tafluprost on the conjunctiva than preserved latanoprost. ${ }^{32}$ Surprisingly, change in Schirmer's test scores was smaller and statistically significant only at week 6 of treatment with the preservativefree tafluprost formulation. ${ }^{32}$

\section{Patient compliance and comfort}

Tafluprost and preservative-free tafluprost formulations were introduced onto the market in 2008. This is probably the reason for the relative lack of data on patient satisfaction and compliance. In the Uusitalo study, the Comparison of Ophthalmic Medications or Tolerability questionnaire devised by Barbel et al was used to assess drop discomfort in patients treated with preserved latanoprost and switched to preservative-free tafluprost. ${ }^{32,56}$ As the authors described, among patients receiving the commercially available latanoprost formulation, 30\% experienced no negative effect on quality of life, $59 \%$ experienced "a little or some", 10\% "quite a bit or very much", and 1\% "extremely negative". ${ }^{32}$ After switching to preservative-free tafluprost, no negative effect on quality of life was reported by $52 \%$ of enrolled patients, $46 \%$ reported "a little or some", $2 \%$ "quite a bit" and $0 \%$ "very much or extremely" after 12 weeks of this therapy. The percentage of latanoprost patients who were totally satisfied with therapy at baseline was $16 \%$, and $36 \%$ were very satisfied. At week 12 of treatment with preservative-free tafluprost, $32 \%$ of patients were totally satisfied and $45 \%$ were very satisfied. ${ }^{32}$ In another study, patients with poor local tolerance of their medications noticed improvement of subjective symptoms and clinical signs after changing their therapy to preservative-free tafluprost $0.0015 \% .{ }^{35}$ Similar analyses are needed to compare safety, tolerability, patient compliance, and comfort between tafluprost and the other prostaglandin analogs.

\section{Conclusion}

Both preserved and preservative-free formulations of tafluprost are relatively new regimens for glaucoma treatment. The results of existing clinical studies of tafluprost use are very promising. Despite several studies concerning its efficacy, safety, and tolerability, the positioning of tafluprost among the antiglaucoma drugs is not well established yet. Further analysis is likely to achieve this in the near future.

\section{Disclosure}

The author reports no conflicts of interests in this work.

\section{References}

1. Flammer J. Pathogenesis of glaucomatous optic neuropathy (GON). $A d v$ Clin Exp Med. 2004;13(3):389-394.

2. Yee RW. The effect of drop vehicle on the efficacy and side effects of topical glaucoma therapy: A review. Curr Opin Ophthalmol. 2007; 18(2):134-139.

3. Uusitalo H, Kaarniranta K, Ropo A. Pharmacokinetics, efficacy and safety profiles of preserved and preservative-free tafluprost in healthy volunteers. Acta Ophthalmol. 2008;86 Suppl 242:S7-S13.

4. Sutton A, Gouws P, Ropo A. Tafluprost, a new potent prostanoid receptor agonist: A dose-response study on pharmacodynamics and tolerability in healthy volunteers. Int J Clin Pharmacol Ther. 2008;46(8):400-406.

5. Gordon MO, Beiser JA, Brandt JD, et al. The Ocular Hypertension Treatment Study. Baseline factors that predict the onset of primary open-angle glaucoma. Arch Ophthalmol. 2002;120(6):714-720.

6. Miglior S, Torri V, Zeyen T, Pfeifler N, Vaz JC, Adamsons J. European Glaucoma Prevention Study (EGPS) Group. Intercurrent factors associated with the development of open-angle glaucoma in the European Glaucoma Prevention Study. Am J Ophthalmol. 2007;144(2): 266-275.

7. Bengtsson B, Leske MC, Hyman L, Heijl A. Fluctuation of intraocular pressure and glaucoma progression in the Early Manifest Glaucoma Trial. Ophthalmology. 2007;114(2):205-209.

8. Mush DC, Gillespie BW, Niziol LM, et al. Factors associated with intraocular pressure before and during 9 years of treatment in the Collaborative Initial Glaucoma Treatment Study. Ophthalmology. 2008; 115(6):927-933.

9. The AGIS Investigators. The Advanced Glaucoma Intervention Study (AGIS): 12. Baseline risk factors for sustained loss of visual field and visual acuity in patients with advanced glaucoma. Am J Ophthalmol. 2002;134(4):499-512. 
10. Collaborative Normal Tension Glaucoma Study Group. The effectiveness of intraocular pressure reduction in the treatment of normal tension glaucoma. Am J Ophthalmol. 1998;126(4):498-505.

11. Hamacher T, Airaksinen J, Saarela V, Liinamaa MJ, Richter U, Ropo A. Efficacy and safety levels of preserved and preservative-free tafluprost are equivalent in patients with glaucoma or ocular hypertension: Results from a pharmacodynamics analysis. Acta Ophthalmol. 2008;86 Suppl 242:S14-S19.

12. van der Valk R, Webers CA, Schouten JS, Zeegers MP, Hendrikse F, Prins MH. Intraocular pressure-lowering effects of all commonly used glaucoma drugs: A meta-analysis of randomized clinical trials. Ophthalmology. 2005;112(7):1177-1185.

13. European Glaucoma Society. Heij1 A, Traverso C, editors. Terminology and Guidelines for Glaucoma. 3rd ed. Savona: Editrice Dogma; 2008.

14. Ishida N, Odani-Kawabata N, Shimazaki A, Hara H. Prostanoids in the therapy of glaucoma. Cardiovasc Drug Rev. 2006;24(1):1-10.

15. Camras CB, Bito LZ, Eakins KE. Reduction of intraocular pressure by prostaglandins applied topically to the eyes of conscious rabbits. Invest Ophthalmol Vis Sci. 1977;16(12):1125-1134.

16. Muñoz- Negrete FJ, Pérez-López M, Won Kim HR, Rebolleda G. New developments in glaucoma medical treatment. Arch Soc Esp Oftalmol. 2009;84(10):491-500.

17. Nakajima T, Matsugi T, Goto W, et al. New fluoroprostaglindin F(2alpha) derivatives with prostanoid FP-receptor agonistic activity as potent ocular-hypotensive agents. Biol Pharm Bull. 2003;26(12): 1691-1695.

18. Ota T, Aihara M, Narumiya S, Araie M. Effects of protaglandinanalogues on IOP in prostanoid FP receptor deficient mice. Invest Ophthalmol Vis Sci. 2005;46(11):4159-4163.

19. Ota T, Murata H, Sugimoto E, Aihara M, Araie M. Protaglandin analogues and mouse intraocular pressure: Effects of tafluprost, latanoprost, travoprost, and unoprostone, considering 24 hour variation. Invest Ophthalmol Vis Sci. 2005;46(6):2006-2011.

20. Ota T, Aihara M, Saeki T, Naumiya S, Araie M. The IOP-lowering effects and mechanism of action of tafluprost in prostanoid receptor-deficient mice. Br J Ophthalmol. 2007;91(5):673-676.

21. Aihara M. Clinical appraisal of tafluprost in the reduction of elevated intraocular pressure (IOP) in open-angle glaucoma and ocular hypertension. Clin Ophthalmol. 2010;4:163-170.

22. Szumny D. Leki stosowane w terapii jaskry. In: Misiuk-Hojło M, Szumny D, Jurowska-Liput J, Krzyżanowska-Berkowska P, editors. Farmakoterapia jaskry. Wrocław: Górnicki Wydawnictwo Medyczne; 2008:9-45.

23. Sutton A, Gilvarry A, Ropo A. A comparative, placebo-controlled study of prostanoid fluoroprostaglandin-receptor agonists tafluprost and latanoprost in healthy males. J Ocul Pharmacol Ther. 2007;23(4): 359-365.

24. Takagi Y, Nakajima T, Shimazaki A, et al. Pharmacological characteristics of AFP-168 (tafluprost), a new prostanoid FP receptor agonist as an ocular hypotensive drug. Exp Eye Res. 2004;78(4):767-776.

25. Akaishi T, Odani-Kawabada N, Ishida N, Nakamura M. Ocular hypotensive effects of anti-glaucoma agents in mice. JOcul Pharmacol Ther. 2009;25(5):401-408.

26. Dong Y, Watabe H, Su G, Ishikawa H, Sato N, Yoshitomi T. Relaxing effect and mechanism of tafluprost on isolated rabbit ciliary arteries. Exp Eye Res. 2008;87(3):251-256

27. Akaishi T, Kutrashima H, Odani-Kaeabata N, Ishida N, Nakamura M. Effects of repeated administration of tafluprost, latanoprost, and travoprost on optic nerve blood flow in conscious normal rabbits. J Ocul Pharmacol Ther. 2010;26(2):181-186.

28. Mayama C, Ishii K, Saeki T, Ota T, Tomodokoro A, Araie M. Effects of topical phenylephrine and tafluprost on optic nerve head circulation in monkeys with unilateral experimental glaucoma. Invest Ophthamol Vis Sci. 2010;51(8):4117-4124.

29. Izumi N, Nagaoka T, Sato E, et al. Short-term effects of topical tafluprost on retinal blood flow in cats. J Ocul Pharmacol Ther. 2008;24(5): 521-526.
30. Harris A, Rusia D, Moss A, et al. Ocular Blood flow in Glaucoma. Myths and Reality. Amsterdam: Kugler Publications; 2009.

31. Kanamori A, Naka M, Fukuda M, Nakamura M, Negi A. Tafluprost protects rat retinal ganglion cells from apoptosis in vitro and in vivo. Graefes Arch Clin Exp Ophthalmol. 2009;247(10):1353-1360.

32. Uusitalo H, Chen E, Pfeiffer N, et al. Switching from a preserved to a preservative-free prostaglandin preparation in topical glaucoma medication. Acta Ophthalmol. 2010;88(3):329-336.

33. Traverso CE, Ropo A, Papadia M, Uusitalo H. A phase II study on the duration and stability of the intraocular pressure-lowering effect and tolerability of tafluprost compared with latanoprost. J Ocul Pharmacol Ther. 2010;26(1):97-104.

34. Uusitalo H, Pillunat LE, Ropo A. Efficacy and safety of tafluprost $0.0015 \%$ versus latanoprost $0.005 \%$ eye drops in open-angle glaucoma and ocular hypertension: 24-month results of a randomized, doublemasked phase III study. Acta Ophthalmol. 2010;88(1):12-19.

35. Hommer A, Mohammed RO, Burchert M, Kimmich F. IOP-lowering efficacy and tolerability of preservative-free tafluprost $0.0015 \%$ among patients with ocular hypertension or glaucoma. Curr Med Res Opin. 2010;26(8):1905-1913.

36. Egorov E, Ropo A. Adjunctive use of tafluprost with timolol provides additive effects for reduction of intraocular pressure in patients with glaucoma. Eur J Ophthalmol. 2009;19(2):214-222.

37. Choy SY, Choy CK, Kuang TM, Hsu WM. The incidence and severity of iris pigmentation in latanoprost treated glaucoma eyes. Eye. 2005;19(7): 784-787.

38. Pożarowska D. Toxic effects of antiglaucoma drugs on superficial tissues of the eye. Int Rev Allergol Clin Immunol. 2008;14(3-4):10-4.

39. Brodway DC, Grierson I, Hitchings RA. Adverse effects of topical antiglaucomatous medications on the conjunctiva. Br J Ophthalmol. 1993;77(9):590-596.

40. Brodway DC, Grierson I, O'Brien C, Hitchings RA. Adverse effects of topical antiglaucomatous medications on the conjunctiva. II: The outcome of filtration surgery. Arch Ophthalmol. 1994;112(11): 1446-1454.

41. Pozarowska D, Pozarowski P, Darzynkiewicz Z. Cytometric assessment of cytostatic and cytotoxic effects of topical glaucoma medications on human epithelial corneal line cells. Cytometry Part B. 2010;78B(2): $130-137$.

42. Thygesen J. In search of improved prostaglandin treatment for glaucoma. Acta Ophthalmol. 2008;86 Suppl 242:S5-S6.

43. de Saint JM, Debbasch C, Brignole F, et al. Toxicity of preserved and unpreserved antiglaucoma topical drugs in an vitro model of conjunctival cells. Curr Eye Res. 2000;20(2):85-94.

44. Brasnu E, Brignole-Baudouin F, Riancho L, Warnet JM, Baudouin C. Comparative study on the cytotoxic effect of benzalkonium chloride on the Wong-Kilboure derivative of Chang conjunctival and IOBA-NHC cell lines. Mol Vis. 2008;14:394-402.

45. Liang H, Baudouin C, Pauly A, Brignole-Baudouin F. Conjunctival and corneal reactions in rabbits following short- and repeated exposure to preservative-free tafluprost, commercially available latanoprost and $0.02 \%$ benzalkonium chloride. Br J Ophthalmol. 2008;92(9): 1275-1282.

46. Baudouin C, Riancho L, Warnet JM, Brignole F. In vitro studies of antiglaucomatous prostaglandin analogues: Travoprost with and without benzalkonium chloride and preserved latanoprost. Invest Ophthalmol Vis Sci. 2007;48(9):4123-4128.

47. Mietz H, Niesen U, Krieglstein GK. The effects of preservatives and antiglaucomatous medication on histopathology of the conjunctiva. Graefes Arch Clin Exp Ophthalmol. 1994;232(9):561-565.

48. Baudoin C, Pisella PJ, Goldschild M, et al. Ocular surface inflammatory changes induced by topical antiglaucoma drugs. Ophthalmology. 1999; 106(3):556-563.

49. Brignole F, Becquet F, Pisella J, et al. Expression of Fas antigen (CD45) in the human conjunctival epithelium: Positive correlation with class II HLA DR expression in inflammatory conditions. Exp Eye Res. 1998; 67(6):687-697. 
50. Pisella PJ, Debbasch C, Hamard P, et al. Conjunctival proinflammatory and proapoptotic effect of latanoprost and preserved and unpreserved timolol: An ex vivo and in vitro study. Invest Ophthalmol Vis Sci. 2004; 45(5):1360-1368.

51. Guenoun JM, Baudouin C, Rat P, Pauly A, Warnet JM, BrignoleBaudouin F. In vitro comparison of cytoprotective and antioxidative effects of latanoprost, travoprost, and bimatoprost on conjunctiva-derived epithelial cells. Invest Ophthalmol Vis Sci. 2005;46(12):4594-4599.

52. Guenoun JM, Baudouin C, Rat P, Pauly A, Warnet JM, BrignoleBaudouin F. In vitro study of inflammatory potential and toxicity profile of latanoprost, travoprost, and bimatprost in conjunctiva-derived epithelial cells. Invest Ophthalmol Vis Sci. 2005;46(12):2444-2450.

53. Smith JA, Albeitz J, Begley C, et al. The epidemiology of dry eye disease: Report of the Epidemiology Subcommittee of the International Dry Eye Workshop. Ocul Surf. 2007;5(2):93-107.
54. Brasnu E, Brignole-Baudouin F, Riancho L, Guenoun JM, Warnet JM, Baudouin C. In vitro effects of preservative-free tafluprost and preserved latanoprost, travoprost, and bimatoprost in a conjunctival epithelial cell line. Curr Eye Res. 2008;33(4D):302-312.

55. Pellinen P, Lokkila J. Corneal penetration into rabbit aqueous humor is comparable between preserved and preservative-free tafluprost. Ophthalmic Res. 2009;41(2):118-122.

56. Barbel BL, Strahlman ER, Laibovitz R, Guess HA, Reiness SA. Validation of questionnaire for comparing the tolerability of ophthalmic medications. Ophthalmology. 1997;104(2):334-342.
Clinical Ophthalmology

\section{Publish your work in this journal}

Clinical Ophthalmology is an international, peer-reviewed journal covering all subspecialties within ophthalmology. Key topics include: Optometry; Visual science; Pharmacology and drug therapy in eye diseases; Basic Sciences; Primary and Secondary eye care; Patient Safety and Quality of Care Improvements. This journal is indexed on

\section{Dovepress}

PubMed Central and CAS, and is the official journal of The Society of Clinical Ophthalmology (SCO). The manuscript management system is completely online and includes a very quick and fair peer-review system, which is all easy to use. Visit http://www.dovepress.com/ testimonials.php to read real quotes from published authors. 